\title{
Carbon Sequestration Potential of Tree Species in the Premises of Various Educational Institutes, Vijaypur (J\&K), India
}

\author{
Kulvinder Kour, Sanjay Sharma \\ Department of Environmental Sciences, University of Jammu, India
}

\begin{abstract}
In the present investigation, aboveground and belowground carbon sequestration potential of tree species growing in various educational institutions of Vijaypur, Samba, J\&K was assessed. In various institutions of study area, a total of 13 species of trees belonging to 10 families were found in randomly selected sample plots. The diameter at breast height (DBH) of each tree was recorded using ground measurements. Total biomass and carbon sequestrated by the tree species was estimated using non-destructive method and allometric equations. The aboveground and belowground organic carbon (ton/tree) and total organic carbon (ton) of each species was calculated. The results of the study show that Ficus religiosa was the predominant species with highest carbon storage, of both above and below components, to the tune of 17.51 ton/ha followed by Ficus benghalensis (5.64 ton of carbon per ha) whereas the value of carbon sequestered was observed least for Annona Squamosa i.e. 0.05 ton/ ha.
\end{abstract}

Keywords: Trees, educational institutions, carbon sequestration, biomass, non-destructive method, etc.

\section{INTRODUCTION}

Carbon sequestration in terrestrial ecosystem is referred as the absorption of $\mathrm{CO}_{2}$ from the atmosphere by photosynthesis. Carbon sequestration is a mechanism for the removal of carbon from the atmosphere by storing it in the biosphere (Chavan and Rasal, 2012). Carbon sequestration in growing forests is known to be a cost-effective option for mitigation of global warming and global climatic change. Estimates of carbon stocks and stock changes in tree biomass (above and belowground) are necessary to study climate change under United Nations Framework Convention on Climate Change (Green et al., 2007). The increasing carbon emission is of major concern for entire world as addressed in Kyoto protocol (Chavan and Rasal 2010; Ravindranath et al., 1997). Terrestrial vegetation and soil represents important sources and sinks of atmospheric carbon (Watson et al., 2000). The present study deals with the estimation of tree biomass, carbon storage and sequestration in the campuses of various educational institutes. Such studies highlight the role of tree cover in carbon sequestration and emphasize the need for greater attention to be paid to the selection of trees in the educational institutes that supports biodiversity and maximizes environmental services.

\section{MATERIAL AND METHODS}

\subsection{Study Area}

The area selected for study i.e. Vijaypur Block of Samba District. The head quarter of district Samba is situated in range of Shivalik hills alongside the National Highway 1-A/ on the bank of river Basantar at a distance of $40 \mathrm{~km}$. from Jammu city.

The materials used for reconnaissance of the study area were the topo-maps at a scale of 1:50,000 and the Google image of the study area. The methodology of Forest Survey of India Dehradun, (FSI, 2006), was followed for the assessment of Trees Outside Forest (Rural) (TOF-R) in the study area.

The plants having girth of more than or equal to $25 \mathrm{~cm}$ were considered as trees and their circumference at breast height (1.3 meters above the ground) was measured. The information collected regarding trees was used for phyto-sociological analysis. An inventory of trees species was prepared with family of each species mentioned in the inventory. The quantitative analysis of frequency, density and abundance was done by using the standard expressions. The importance value index (IVI) was determined as the sum of relative frequency, relative density and relative dominance. 

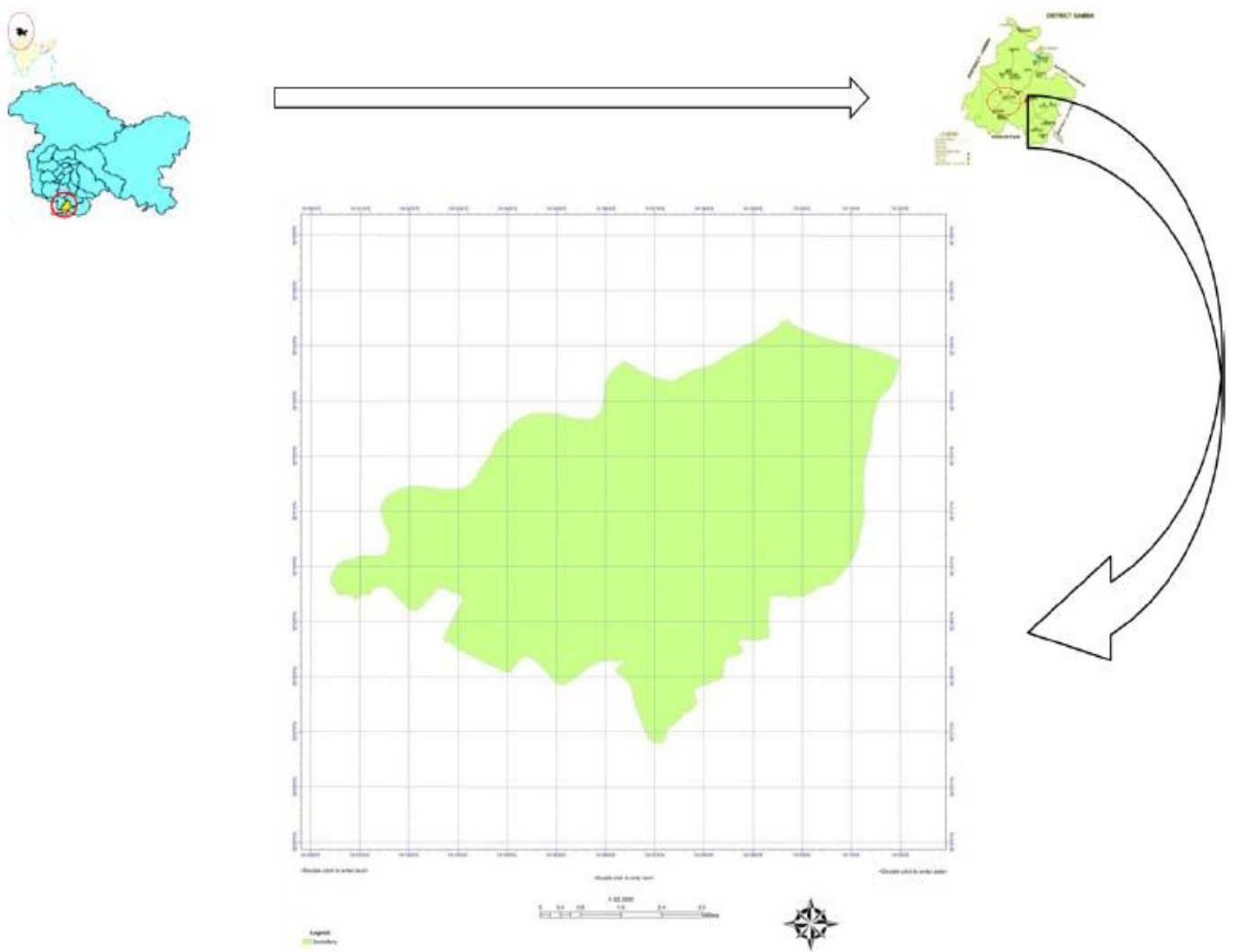

Fig1. Location map of Block Vijaypur

The importance value index (IVI of species), the percentage values of relative frequency, relative density and relative dominance of each tree species were summed up (Curtis, 1959), which determines vegetation status and importance of component species with in a stratum. The Abundance - Frequency ratio was calculated and used to interpret the distribution pattern of the species. This ratio indicates regular $(<0.025)$, random $(0.025-0.05)$ and contagious $(>0.05)$ distribution pattern (Whitford, 1949). Species diversity was computed by using Shannon Weiner index (1949). The aboveground biomass (AGB) was calculated by multiplying volume of biomass and wood density, the volume was calculated based on diameter (Pandya et al., 2013). The belowground biomass (BGB) was calculated by multiplying above ground biomass taking 0.26 as the root shoot ratio (Chavan and Rasal, 2011; Hangarge et al., 2012). By summing the above and below ground biomass the total biomass was calculated (Sheikh et al. 2011).

\section{Total Biomass $(\mathrm{TB})=$ Above Ground Biomass + Below Ground Biomass}

The carbon content of each tree was calculated by multiplying the total biomass of the species by a conversion factor 0.475 (Singh and Chand, 2013).

\section{RESUlTS AND DisCUSSION}

In various institutions of study area, a total of 13 species of trees belonging to 10 families were recorded with Syzygium cumini having the highest basal area of $8.69 \mathrm{~m}^{2} /$ ha followed by Ficus religiosa $\left(7.57 \mathrm{~m}^{2} / \mathrm{ha}\right)$, whereas, the least was observed in case of Alstonia scholaris $\left(0.67 \mathrm{~m}^{2} / \mathrm{ha}\right)$. Alstonia scholaris was found the most dense species (22.5 tree/ha) in the premises of various institutions followed by Ficus religiosa and Melia azedarach with density values of 20 tree/ha and 10 tree/ha, respectively. In contrast to it, a study conducted by Kour and Sharma (2014) in the agricultural fields of block Ramgarh revealed Mangifera indica as the most dense tree species with density value of 1.9 trees per hectare followed by Melia azedarach having density of 1.1 trees per hectare.

The results pertaining to abundance of tree species in the study area revealed that Ficus religiosa and Melia azedarach were the most abundant species with value of 2.67 each. Alstonia scholaris was observed to be having second most abundant species with value of 2.57 and was also found the most frequent species in the study area with value of 35 percent. The next high frequent species was Ficus religiosa (30\%). In contrast to this, Pune University campus was dominated by evergreen trees such 
Carbon Sequestration Potential of Tree Species in the Premises of Various Educational Institutes, Vijaypur (J\&K), India

as Mangifera indica, Ficus benghalensis, etc (Haghparast et al., 2013). Some of the least abundant species were Artocarpus heterophyllus, Acacia nilotica, Annona squamosa, Mangifera indica and Sygygium cumini, each with abundance value of 1 whereas the least frequent species were Tectona grandis, Acacia nilotica, Annona squamosa and Artocarpus heterophyllus each with frequency value of 5 percent.

The highest importance value index among the trees was observed for Ficus religiosa (59.72) with highest share of relative dominance $(21.53 \%)$ followed by relative density $(21.05 \%)$ and relative frequency $(17.14 \%)$. The second highest value of IVI was obtained for Alstonia scholaris (45.59). The distribution of different trees species in the various institutions was mainly contagious. The value of Shannon -Weiner's index found to be 2.18. In similar study conducted in the agricultural fields of Ramgarh block, the value of Shannon -Weiner's index was found to be 2.41 (Kour and Sharma, 2014), which is higher than that of diversity of trees in educational institutions.

Table1. Phytosociological Parameters for Tree in the premises of various Institutes

\begin{tabular}{|c|c|c|c|c|c|c|c|c|c|c|c|}
\hline \multirow[t]{2}{*}{\begin{tabular}{|l} 
S. \\
No.
\end{tabular}} & \multirow[t]{2}{*}{ Botanical name } & \multirow[t]{2}{*}{ Family } & \multirow{2}{*}{$\begin{array}{l}\text { Average } \\
\text { Basal } \\
\text { Area } \\
\left(\mathrm{m}^{2} / \mathrm{ha}\right)\end{array}$} & \multirow[t]{2}{*}{$\begin{array}{l}\text { Average } \\
\text { Density } \\
\text { (tree/ha) }\end{array}$} & \multirow[t]{2}{*}{$\begin{array}{l}\mathrm{A} / \mathrm{F} \\
\text { ratio }\end{array}$} & \multirow[t]{2}{*}{ IVI } & \multirow{2}{*}{$\begin{array}{l}\text { Average } \\
\text { Volume } \\
\left(\mathrm{m}^{3} / \mathrm{ha}\right)\end{array}$} & \multicolumn{3}{|c|}{$\begin{array}{l}\text { Average Biomass } \\
\text { (ton/ha) }\end{array}$} & \multirow{2}{*}{$\begin{array}{l}\text { Average } \\
\text { Organic } \\
\text { carbon } \\
\text { (ton/ha) }\end{array}$} \\
\hline & & & & & & & & AGB & BGB & Total & \\
\hline 1 & Ficus benghalensis L. & Moraceae & 5.55 & 5 & 0.09 & 29.62 & 23.80 & 11.75 & 3.05 & 14.8 & 5.64 \\
\hline 2 & Tectona grandis L.F. & Lamiaceae & 0.69 & 2.5 & 0.40 & 7.46 & 0.55 & 0.26 & 0.07 & 0.33 & 0.13 \\
\hline 3 & Mangifera indica $\mathrm{L}$. & Anacardiaceae & 4.18 & 2.5 & 0.10 & 20.25 & 3.78 & 2.23 & 0.57 & 2.8 & 1.06 \\
\hline 4 & Acacia nilotica $\mathrm{L}$. & Mimosaceae & 2.07 & 1.25 & 0.20 & 10.06 & 0.36 & 0.24 & 0.06 & 0.3 & 0.12 \\
\hline 5 & $\begin{array}{l}\text { Alstonia scholaris } \\
\text { L.R.Br }\end{array}$ & Apocynaceae & 0.67 & 22.5 & 0.07 & 45.59 & 4.02 & 2.13 & 0.55 & 2.68 & 1.02 \\
\hline 6 & \begin{tabular}{|l} 
Artocarpus \\
heterophyllus Lam
\end{tabular} & Moraceae & 1.15 & 1.25 & 0.20 & 7.44 & 0.35 & 0.19 & 0.05 & 0.24 & 0.09 \\
\hline 7 & Annona squamosa $\mathrm{L}$. & Annonaceae & 0.79 & 1.25 & 0.20 & 6.42 & 0.24 & 0.12 & 0.03 & 0.15 & 0.05 \\
\hline 8 & Morus alba Linn. & Moraceae & 0.82 & 7.5 & 0.13 & 18.78 & 0.78 & 0.42 & 0.11 & 0.53 & 0.19 \\
\hline 9 & Ficus religiosa $\mathrm{L}$. & Moraceae & 7.57 & 20 & 0.09 & 59.72 & 93.78 & 36.48 & 9.48 & 45.96 & 17.51 \\
\hline 10 & $\begin{array}{l}\text { Syzygium cumini (L.) } \\
\text { Skeels }\end{array}$ & Myrtaceae & 8.69 & 2.5 & 0.10 & 33.07 & 5.96 & 3.86 & 1.00 & 4.86 & 1.85 \\
\hline 11 & Melia azedarach $\mathrm{L}$. & Meliaceae & 0.77 & 10 & 0.18 & 21.27 & 1.80 & 0.90 & 0.23 & 0.32 & 0.43 \\
\hline 12 & $\begin{array}{l}\text { Dalbergia sissoo } \\
\text { Roxb. }\end{array}$ & Fabaceae & 1.18 & 8.75 & 0.16 & 21.14 & 2.08 & 0.81 & 0.21 & 1.02 & 0.39 \\
\hline 13 & $\begin{array}{l}\text { Populus ciliata } \\
\text { Wall.ex Royle }\end{array}$ & Salicaceae & 1.03 & 10 & 0.40 & 19.18 & 2.21 & 0.82 & 0.21 & 1.03 & 0.39 \\
\hline \multicolumn{3}{|c|}{ Shannon Weiner Index } & \multicolumn{4}{|c|}{$\frac{1}{2.18}$} & \multicolumn{4}{|c|}{ Total Carbon Sequesteration } & 28.91 \\
\hline
\end{tabular}

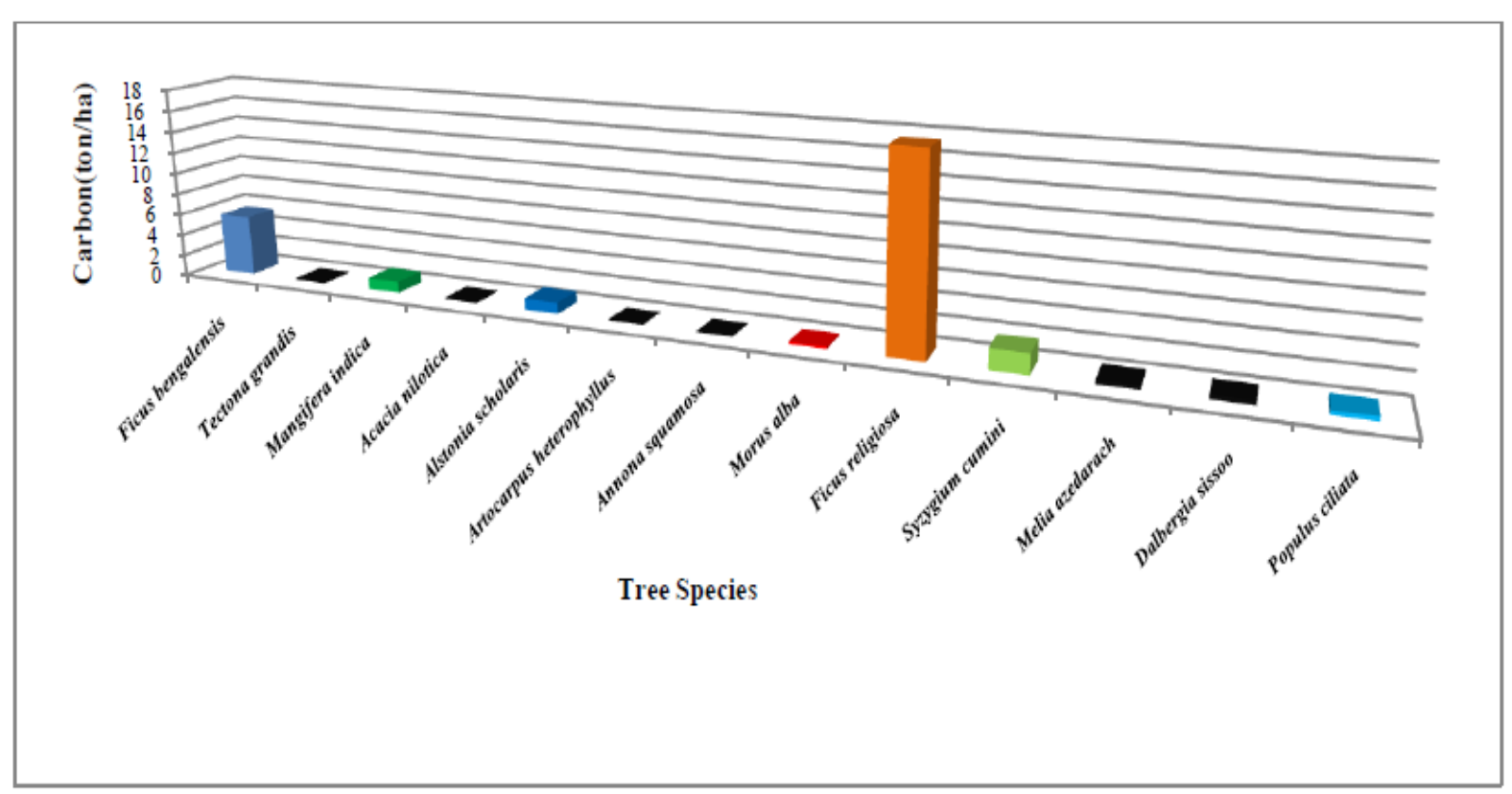

Fig2. Cumulative total sequestered carbon $\left(\right.$ tha $\left.{ }^{-1}\right)$ by tree species 


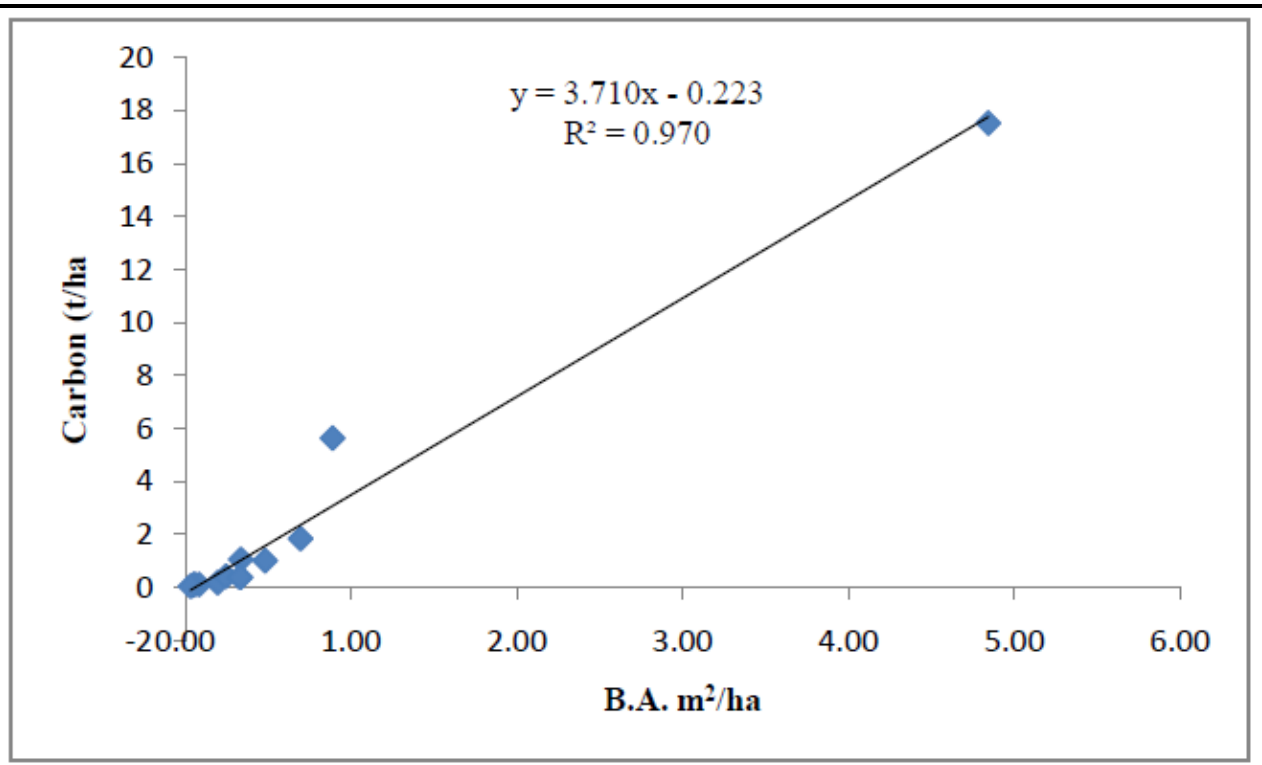

Fig3. Relationship between basal area and Carbon sequestration of various tree species

Maximum above ground and below ground biomass was also assessed and was found highest for Ficus religiosa i.e. 36.48 t/ha and 9.48 t/ha respectively (Table 1), followed by Ficus banghalensis (11.75 and $3.05 \mathrm{t} / \mathrm{ha})$. The other major carbon sequestratating species were Syzygium cumini (1.85 t/ha) and Mangifera indica (1.06 t/ha). A study was also carried out by Chavan and Rasal (2010) with regard to standing carbon stock in selective tree species growing in Dr. B.A.M. University campus at Aurangabad and the results revealed that the average standing stock of organic carbon was about 1.65 t/tree. In another similar study conducted by Suryawanshi et al. (2014) in North Maharashtra University campus where they found that Tectona grandis species was dominant species having 244 trees and sequestering 1.915 tons of carbon. Trees with minimum carbon sequestration in the study area were Annona squamosa (0.05 t/ha), Artocarpus heterophyllus $(0.09 \mathrm{t} / \mathrm{ha})$, Tectona grandis $(0.13$ t/ha) and Morus alba (0.19 t/ha). Alstonia scholaris was the most dense species in various school campuses having 18 individuals with value of $1.02 \mathrm{t}$ sequestered carbon (fig 2). Basal area of different tree species was also significantly positively correlated with sequestered carbon (fig. 3). Although in many schools, there were plantation of Alstonia scholaris but the trees were very young having plant girth less than $25 \mathrm{~cm}$.

\section{Conclusion}

Total average standing biomass of various tree species was calculated to be 75.88 tons/ha, whereas, total average carbon sequestered was 28.91 tons/ha. Carbon sequestration capacity of tree increases as the age increases. Therefore, it can be concluded that the older trees have higher carbon content than younger trees. Moreover, old trees are the reservoirs of carbon. In order to protect the world from global warming and climatic change, the sustainable management of forests with the objectives of carbon sequestration is mandatory. The results of this study may facilitate further planning and decision-making regarding plantation in the campuses of various educational institutions because there is a need for better management and conservation of the biodiversity in that area.

\section{ACKNOWLEDGEMENTS}

The authors wish to thank the Department of Environmental Sciences, University of Jammu for providing necessary facilities and encouragement.

\section{REFERENCES}

Chavan BL and Rasal GB (2010). Sequestered standing carbon stock in selective tree species grown in University campus at Aurangabad, Maharashtra, India. IJEST, 2(7): 3003-3007.

Chavan BL and Rasal GB (2011). Sequestered Carbon Potential and Status of Eucalyptus Tree. International Journal of Applied Engineering and Technology, 1(1):41-47.

Chavan BL and Rasal GB (2012). Carbon Sequestration Potential of young Annona Reticulate and Annona squamosa from University Campus of Aurangabad. International Journal of Physical and Social Sciences. 2(3): 193-198. 
Carbon Sequestration Potential of Tree Species in the Premises of Various Educational Institutes, Vijaypur (J\&K), India

Curtis JT (1959). The vegetation of Wisconsin. An Ordination of plant Communities, University of Wisconsin Press, Madison Wisconsin, pp. 657.

FSI (2006). Volume equations for forests of India, Nepal and Bhutan. Forest Survey of India, Ministry of Environmental and Forests, Dehradun.

Green R, Tobin B and O'Shea M (2007). Above and below ground biomass measurements in an unthinned stand of Sitka spruce (Piceasitchensis (Bong) Carr.). Eur. J. forest Res., 126: 179-188.

Haghparast H, Delbari A and Kulkarni D K (2013). Carbon sequestration in Pune university campus with special reference to geographical information system (GIS). Annals of Biological Research, 4 (4):169-175

Hangarge LM, Kulkarni DK, Gaikwad VB, Mahajan DM and Chaudhari N (2012). Carbon Sequestration potential of tree species in Somjaichi Rai (Sacred grove) at Nandghur village, in Bhor region of Pune District, Maharashtra State, India. Annals of Biological Research, 3(7):3426-3429.

Kour K and Sharma S (2014). Potential of Agroforestry, Inventorization, Distribution Pattern and Phytosociological Analysis of Tree Species in Block Ramgarh, Samba (J\&K), India. International Journal of Advances in Agricultural Science and Technology, 2(6) pp:19-25

Pandya IY, Salvi H, Chahar O and Vaghela N (2013) Quantitative Analysis on Carbon Storage of 25 Valuable Tree Species of Gujarat, Incredible India. Indian J.Sci.Res., 4(1):137-141.

Ravindranath NH, Somashekhar BS and Gadgil M, (1997). Carbon flow in Indian forests, submitted to the Ministry of Environment and Forest. Climate change, 35(3): 297-320

Shannon CE and Weiner W (1949). The mathematical theory of communication. University of Illinois press, Urbana, USA. pp117.

Sheikh MA, Kumar MB and Wand TNP (2011). Forest carbon stocks and fluxes in physiographic zones of India. Carbon Balance and Management, 6(15): 1186-1750.

Singh $\mathbf{K}$ and Chand $\mathbf{P}$ (2012). Above-ground tree outside forest (TOF) phytomass and carbon estimation in the semi-arid region of southern Haryana: A synthesis approach of remote sensing and field data. J. Earth Syst, 121(6): 1469-1482.

Suryawanshi MN, Patel AR, Kale TS and Patil PR (2014). Carbon sequestration potential of tree species in the environment of North Maharashtra University Campus, Jalgaon (MS) India. Bioscience Discovery, 5(2):175-179

Watson RT and Core WT (2001). Climate change 2001: Synthesis report - An Assessment of the Intergovernmental Panel of Climate Change. Contribution of Working Groups I, II, and III to the Third Assessment Report of the Intergovernmental Panel on Climate Change (IPCC). CambridgeUniversityPress, Cambridge. 35-145(397).

Whitford PB (1949). Distribution of woodland plants in relation to succession and clonal growth.Ecology.30,pp199288 